\title{
Qualified Immunity and the 21-Foot Rule
}

\author{
Bruece Machacynski ${ }^{1}$ \\ ${ }^{1}$ American Military University
}

September 24, 2020

\begin{abstract}
The use of deadly force to counter the threat of a knife attack is a constitutionally permissible means of ensuring police and public safety. This paper reviews the constitutional standard for use-of-force by police, relevant case law, academic literature, statistical tables, and current police methodologies before evaluates the options available to police officers and suggesting a number of measures for minimizing the use of deadly force when encountering a person armed with a knife.
\end{abstract}

\section{Introduction}

The scenario is frighteningly familiar: a woman calls 911 to report her inebriated husband has become violent and is now threatening to harm himself. The police arrive quickly with an array of lethal and lesslethal weaponry: semi-automatic pistols, conducted-energy weapons, and a shotgun loaded with beanbag rounds. The police enter the residence and, as they begin to evacuate the complainants, the suspect suddenly appears holding a knife. The suspect refuses to drop the knife and, with a blank stare, begins to advance towards the officers. The suspect takes a couple of steps before he is repeatedly shot. The officers justify their actions by insisting their actions were an objectively reasonable response to a knife attack. The District Attorney declines to prosecute the officers by noting the suspect was well within the 21-foot safety zone thought necessary to defend against an assailant with a knife. The public is outraged and cannot understand why the heavily armed police officers needed to murder an emotionally disturbed individual holding a kitchen knife in his own home. The city, without admitting liability, offers a multimillion-dollar settlement. There are no winners in this scenario.

The Police Executive Research Forum (PERF) recently released a paper calling for changes in policies, training, tactics, and equipment to provide officers with better tools to address difficult situations like the one detailed above.[1] The report recommended the discontinuation of outdated policing concepts, including the so-called 21-foot rule. As explained by PERF, the 21-foot rule describes the distance an officer must keep from a suspect armed with a knife to give the officer enough time to draw and fire his gun if the suspect suddenly attacks. [2] While it has been widely acknowledged within the law enforcement community that a subject armed with a knife within 21 feet can stab an officer before the officer can shoot the suspect,[3] PERF believes the 21-foot rule has led some officers to believe they are justified in shooting anyone with a knife who gets within 21 feet of them. [4]

There can be little doubt that knives can be dangerous weapons. According to statistics compiled by the Federal Bureau of Investigations (FBI), 9,668 law enforcement officers were assaulted with a knife or other cutting instrument over a 10 year period (2005-2014).[5] In an average year, 967 officers are assaulted and 123 officers injured during knife attacks. Based on the 10-year average, an officer will be attacked with a knife about once every nine hours and injured every third day. Despite the higher injury rate for officers 
assaulted with a knife (12.7\%) compared to those assaulted with a firearm (9.3\%), less than $0.5 \%$ of officers feloniously murdered were killed with a knife compared to more than $92 \%$ killed with a firearm. [6]

The data is open to interpretation. It could be argued that the relatively low police mortality rate is evidence of the effectiveness of current police tactics and techniques for responding to a suspect armed with a knife. It could also be argued that knife attacks, while undeniably dangerous, present a substantially reduced risk of lethality and therefore demand a more measured response from police.

My thesis statement is that the use of deadly force to counter the threat of a knife attack is a constitutionally permissible means of ensuring police and public safety. This paper will review the constitutional standard for use-of-force by police, relevant case law, academic literature, statistical tables, and current police methodologies. Finally, I will defend my thesis by evaluating the options available to police officers and suggest a number of measures for minimizing the need for deadly force when encountering a suspect armed with a knife.

\section{Background}

Officers are wise to keep suspects with knives at a safe distance. As proximity weapons, knives become increasingly dangerous as the suspect approaches. Despite claims that a small knife cannot possibly make an

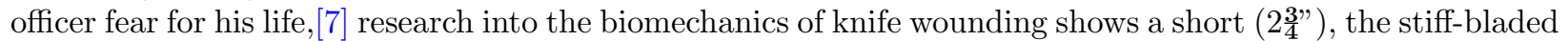
knife is the ideal weapon.[8] While less lethal than gunshot wounds, potentially survivable injuries to the vital area may still result in pre-hospital exsanguination.[9] As most fatal knife attacks involve chest or neck injuries, and less than $25 \%$ of victims are able to make any post-injury physical effort, fear of death following a knife attack is objectively reasonable.[10],[11] Yet it is exceedingly rare for a police officer to be stabbed to death. Even using statistics compiled by the National Law Enforcement Officers Memorial Fund (NLEOMF), only $13(2.5 \%)$ officers were stabbed to death from 2005-2014.[12] For comparison purposes, 1,567 (13.1\%) of the 11,961 murders committed in 2014 were committed with knives or other cutting instruments.[13] To put that in perspective, a member of the public is more than a thousand times more likely to be murdered with a knife than a police officer. Officers know better than most that every shooting, no matter how justified, carries the potential for devastating side-effects, including loss of life, career jeopardy, civil liability, strained community relations, negative media coverage, protests, and civil unrest.[14] Despite these inherent risks, police officers continue to use alarmingly high levels of force when confronting suspects armed with a knife.

\section{The Constitutional Standard}

The Supreme Court, in Tennessee v. Garner, held that the apprehension of a suspect through the use of deadly force is a seizure and subject to the Fourth Amendment's reasonableness requirement.[15] The Court stated plainly that an officer may not always seize a suspect by killing him[16] and that deadly force would not be justified unless the suspect posed an immediate threat to the officer or others.[17] The Court held that deadly force may be permissible if, based on the totality of the circumstances, the suspect threatens the officer with a weapon, and if, where feasible, the officer gives some warning prior to using deadly force.[18] In Graham v Connor, the Court held that the underlying intent or motivation of the officer using force was immaterial and that the reasonableness of a seizure must be judged from the perspective of a reasonable officer on the scene rather than with 20/20 hindsight.[19] The Court recognized that officers must often make split-second judgments in circumstances that are tense, uncertain, and rapidly evolving[20] and articulated a number of factors (known colloquially as Graham factors) that should be considered prior to determine the reasonableness of force, including the severity of the crime at issue; whether the suspect posed an immediate threat to the safety of the officers or others; whether the suspect was actively resisting arrest; and whether the suspect was attempting to evade arrest by flight.[21] Based on Garner and Graham, an officer should 
be justified in using deadly force to repel a knife attack if the suspect threatened the officer with the knife and the officer reasonably believed the suspect posed an immediate threat to his safety.

The Supreme Court, in Rowe v. United States, long ago held that the law does not require a person to stand still and permit himself to be cut to pieces for fear that killing the attacker might result in a conviction for manslaughter.[22] In Brown v. United States, the Court recognized that detached reflection cannot be demanded in the presence of an uplifted knife.[23] The Court held that it would not exceed the bounds of lawful self-defense if a man stood his ground and killed an attacker who reasonably presented an immediate danger of death or grievous bodily harm.[24] While the Court seemed to speak with an abundance of clarity in Rowe and Brown, deadly force jurisprudence has evolved in a myriad of unpredictable ways since.

\section{Recent Court Cases}

In Samples v. Atlanta, the $11^{\text {th }}$ Circuit Court reversed the granting of summary judgment after an officer fatally shot a suspect who, armed with a pocketknife, approached in a threatening manner.[25] The Court held that there was physical evidence from which a fact finder could infer that the officer was excessively violent.[26] The relatively small 3" knife, the difference in size between the officer and the suspect, and the fact that one of the bullets struck the suspect in the back supported an inference that the situation was not as life-threatening as the officer claimed[27] and raised sufficiently serious issues of fact to warrant the denial of qualified immunity.[28]

In Krueger $v$. Fuhr, the $8^{\text {th }}$ Circuit Court reversed the denial of summary judgment after an officer fatally shot a fleeing suspect in the back of the head because he believed the suspect was about to turn around and attack him with a knife.[29] The Court held that it was objectively reasonable for an officer to believe he was in serious and immediate danger when the suspect, who had committed a crime involving the infliction or threatened infliction of serious physical harm, pulled a knife from his waistband.[30]

In Sevier v. City of Lawrence, the $10^{\text {th }}$ Circuit Court affirmed the denial of summary judgment after officers fatally shot a suspect who lunged at the police with a knife in a raised and striking position.[31] The Court held that reasonableness of their actions depended both on whether the officers were in danger at the precise moment they used force and whether their own reckless or deliberate conduct during the seizure unreasonably created the need to use force.[32] The Court found sufficient conflicting evidence as to whether the officers precipitated the use of deadly force by their own actions immediately prior to the shooting.[33]

In Walker v. City of Orem, the $10^{\text {th }}$ Circuit Court affirmed the denial of summary judgment after officers fatally shot a suspect who, holding a small knife to his wrist, made no threats and did not advance.[34] The Court held it was clearly established at the time of the shooting that it was unreasonable for an officer to use deadly force to seize a suspect armed with a knife but neither advancing nor making slicing or stabbing motions.[35]

In Estate of Larsen Ex Rel. Sturdivan v. Murr, the $10^{\text {th }}$ Circuit Court affirmed summary judgment after officers fatally shot a suspect who, armed with a knife raised above his shoulder, took a step towards the officer.[36] Besides the Graham factors, the Court enumerated a number of additional non-exclusive factors that should be considered when assessing the degree of threat faced by an officer, including: whether the officers ordered the suspect to drop his weapon; the suspect's compliance with police commands; whether any hostile motions were made with the weapon; the distance separating the officers and the suspect; and the manifest intentions of the suspect.[37]

In Glenn v. Washington County, the $9^{\text {th }}$ Circuit Court reversed the granting of summary judgment after officers fatally shot a suicidal teenager holding a pocketknife.[38] Interestingly, the Court held that a jury could conclude the officers provoked the need for deadly force after the suspect reacted to being shot with the less-lethal beanbag shotgun. 
In Tenorio $v$. Pitzer, the $10^{\text {th }}$ Circuit Court affirmed the denial of summary judgment after officers shot an intoxicated suspect who was holding the knife loosely in his right hand while slowly walking towards officers.[39] The Court, referring to the factors articulated in Estate of Larsen, found that the suspect was only holding a small kitchen knife by his thigh, did not charge at or make aggressive moves towards the officers, and was not within striking distance when he was shot.[40] Based on the evidence, a jury could believe the suspect did not have enough time to obey the commands to drop the knife and that officers did not have probable cause to believe the suspect posed a threat of serious physical harm to the officers or another person.

In City and County of San Francisco v. Sheehan, the Supreme Court reversed the judgment of the $9^{\text {th }}$ Circuit and concluded officers were entitled to qualified immunity after they shot an unstable woman advancing towards them with a kitchen knife.[41] The $9^{\text {th }}$ Circuit had ruled that a jury could find the officers needlessly provoked the suspect during the confrontation. The Supreme Court held that the officer's failure to accommodate the suspect's mental illness did not violate clearly established law.

\section{Discussion}

Defensive tactics instructors must ensure their training regimes evolve to keep pace with changes in deadly force jurisprudence. What was acceptable 20 years ago may no longer be acceptable today. One way to ensure officers are prepared to handle any situation is to indoctrinate them with a reverence for constitutional policing. Officers must be taught that any force used must be proportionate to the threat faced by the officer based on the totality of the circumstances. The idea of situationally-dependant proportionality often frustrates both new recruits and seasoned officers looking for a definitive solution to an ambiguous problem. The concept of AIM (ability, intent and means) is one way to help officers quickly determine an appropriate response to a given situation. The use of AIM is not a recent phenomenon. In 1883, the Texas Court of Criminal Appeals held that intent to cause murder was a voluntarily committed unlawful act attempted with the means and ability to accomplish it.[42] Using AIM, officers can quickly determine whether the suspect has the physical ability, capability and mobility to cause injury or death and what abilities the officer has to counter the threat; whether the suspect's words and/or actions create the belief that he has the intent to cause injury or death; and whether the suspect possesses the means, medium or mechanism (weapon) to deliver the threat. Without resorting to rigid use-of-force formulations (A plus $\mathrm{B}$ always equals C), officers understand the presence of AIM reasonably predicts the need for pre-emptive countermeasures. Officers must be able to articulate how a suspect closing distance while refusing to drop the knife demonstrates hostile intent coupled with the present ability to deliver a potentially lethal threat.

While the exact number of people killed by police officers each year is unknown, the Federal Bureau of Investigations (FBI) reported 444 justifiable homicides in 2014 and the Bureau of Justice Statistics (BJS) reported average of 419 justifiable homicides per year from 2003 through 2009. [43],[44] The BJS readily admits that its program only captures about half of all law enforcement homicides and neither the FBI nor the BJS disaggregates their data to reveal what, if any, weapon the suspect was carrying at that the time of death. [45] In an attempt to remedy this deeply flawed reporting system, a number of public-interest commercial enterprises have compiled their own lists of police homicides.[46] The Washington Post reported that $140(14 \%)$ of the 990 persons killed by the police in 2015 were armed with a knife[47] while the Guardian claimed 154 (13\%) knife deaths out of the 1,146 fatal police shootings.[48] Despite the discrepancy in the overall tally, both newspapers report a similar proportion $(13.76 \%$ ) of suspects armed with knives when killed by police. An analysis of the murder data from the most recent Uniform Crime Reports (UCR) is informative. Supplemental data collected from 11,961 of the 14,249 homicides committed in 2014 reveals that 1,561 (13\%) were killed with a knife.[49]

The police response to a suspect armed with a knife is an undeniably tense, uncertain, and rapidly evolving endeavor. There is little margin for error and minimal time to formulate a de-escalation strategy. The consequences of mission failure are potentially fatal. The encounter becomes increasingly stressful as the 
number of officers, suspects, bystanders, victims and weapons increases.[50] Despite this, officers are expected to wait until the moment of absolute certainty before employing deadly force. A suspect will be able to cover at least 15 feet before an officer with their pistol at the low-ready position can shot center-of-mass (if the suspect is shot at all).[51] Research has consistently shown that police officers miss their intended targets far more often than not during deadly force encounters.[52]

I believe there is an interesting correlation between the percentage of annual knife murders (about 13\%), the percentage of officers assaulted with knives (about 13\%), and the number of justifiable homicides involving suspects armed with a knife (about 13\%). Although more research is required, it is plausible to conclude the significantly lower percentage of officers killed with knives (less than 3\%) is a result of their pre-emptive use of effective countermeasures. I believe the use of deadly force to counter the threat of a knife attack is a constitutionally permissible means of ensuring police and public safety. While the loss of life is regrettable, deadly force is constitutionally permitted and supported by a growing volume of case law. Statistics and the academic literature support the lethality of knives and the dangers faced by law enforcement. Short of banning all dangerous knives (which King Louis XIV of France attempted in 1669), [53] officers will continue to encounter suspects armed with knives.

\section{Conclusion}

A number of common-sense measures could be implemented to reduce the reliance on deadly force. A properly enforced administrative policy is paramount to effectively controlling police shooting behavior. [54] As best they can, officers should keep a safe distance from suspects armed with a knife and avoid provocative displays of force. Increasing the stand-off distance will have the corollary effect of creating more time for the responding officers to devise a de-escalation plan. Officers should also maximize the use of less-lethal technologies (when lethal overwatch is available) while recognizing the limitations of the tools. Finally, officers must recognize that there is no "one size fits all" solutions in policing. While officers need to remain mindful of the hazards of letting an armed suspect get too close, the decision to use force must be based on the totality of the circumstances and not on a well-intentioned but arbitrary 21-foot rule.

\section{References}

[1] Police Executive Research Forum [PERF], Re-Engineering Training on Police Use of Force (2015).

[2] Id. at 5 .

[3] T. A. Hontz, Justifying the Deadly Force Response, 2 Police Quarterly 462-476 (1999).

[4] PERF, supra at 15.

[5] FBI LEOKA: 2014 (Law Enforcement Officers Assaulted - Type of Weapon and Percent Injured, 20052014)

[6] FBI LEOKA: 2014 (Law Enforcement Officers Feloniously Killed - Type of Weapon, 2005-2014).

[7] Cops Execute Man Carrying Pocket Knife, Filming Cops (2016) http://goo.gl/0aJo7Z (last visited Jun 11, 2016).

[8] M.A. Green, Stab Wound Dynamics - A Recording Technique for Use in Medico-Legal Investigations, 18 Journal of the Forensic Science Society 161-163 (1978).

[9] Juan A. Asensio \& Donald D. Trunkey, Current Therapy of Trauma and Surgical Critical Care 24 (2015).

[10] A. Bleetman et al., Wounding Patterns and Human Performance in Knife Attacks, 10 Journal of Clinical Forensic Medicine 243-248 (2003). 
[11] S.Ø. Thoresen \& T.O. Rognum, Survival Time and Acting Capability after Fatal Injury by Sharp Weapons, 31 Forensic Science International 181-187 (1986).

[12] NLEOMF: Causes of Law Enforcement Deaths (2016), http://goo.gl/vxuuuK (last visited Jun 11, 2016).

[13] FBI Crime in the United States: 2014 (Murder Victims by Weapon, 2010-2014).

[14] William A. Geller \& Michael S. Scott, Deadly Force (1992).

[15] 471 U.S. 1, 7 (1985).

[16] Id. at 9 .

[17] Id. at 11 .

[18] Id. at 11-12.

[19] 490 U.S. 386, 396 (1989).

[20] Id. at 397.

[21] Id. at 396.

[22] 164 U.S. 546, 555 (1896).

[23] 256 U.S. 335, 343 (1921).

[24] $I d$.

[25] 846 F.2d 1328, 12 (11th Cir. 1988).

[26] Id. at 15 .

[27] Id. at 16 .

[28] Id. at 17 .

[29] 991 F.2d 435 (8th Cir.), cert. denied, 510 U.S. 946 (1993).

[30] Id. at 439 .

[31] 60 F. 3d 695 (10th Cir. 1995).

[32] Id. at 699 .

[33] Id. at 701.

[34] 451 F. 3d 1139, 1160 (10th Cir. 2006).

[35] Id.

[36] 511 F.3d 1255, 1259 (10th Cir. 2008).

[37] Id. at 1260 .

[38] 661 F.3d 460 (9th Cir. 2011).

[39] 802 F. 3d 1160 (10th Cir. 2015).

[40] Id. at 1166.

[41] 135 S. Ct. 1765 (2015).

[42] Hayes v. State, 14 Tex.Cr.R. 330 (Tex. Crim. App. 1883).

[43] FBI Crime in the United States: 2014 (Justifiable Homicide by Weapon, Law Enforcement, 2010-2014). 
[44] Andrea M. Burch, Arrest-Related Deaths, 2003-2009 - Statistical Tables, Bureau of Justice Statistics, 2011.

[45] Id. at 1.

[46] D. A. Klinger, On the Problems and Promise of Research on Lethal Police Violence: A Research Note, 16 Homicide Studies 78-96 (2011).

[47] Police Shootings, Washington Post (2016), https://goo.gl/TpwIFs (last visited Jun 11, 2016).

[48] People Killed by Police in the United States, Guardian (2016), http://goo.gl/kK2hg7 (last visited Jun 11, 2016).

[49] "Offenses Known to Law Enforcement: Murder," In Crime in the United States, 2014. Washington: GPO, 2015.

[50] Paul T. Bartone, Enhancing Human Performance in Security Operations 327 (2010).

[51] Hontz, supra at 473.

[52] M. D. White, Hitting the Target (or Not): Comparing Characteristics of Fatal, Injurious, and Noninjurious Police Shootings, 9 Police Quarterly 303-330 (2006).

[53] Emma Hern et al., Reducing Knife Crime, 330 BMJ 1221-1222 (2005).

[54] M. D. White, Controlling Police Decisions to Use Deadly Force, 47 Crime \& Delinquency 132 (2001).

\section{Acknowledgments}

This paper and the research behind it would not have been possible without the support of my supervisor, Dr. Kevin Brannon. His enthusiasm, knowledge, and unnerving attention to detail have driven me to achieve more than I thought possible. 